\title{
Pengaruh Zona Penempatan Berbeda pada Closed Housed terhadap Mikroklimatik Amonia, Bobot Relatif Organ Limfoid, Kelenjar Tiroid, dan Usus Halus pada Ayam Broiler
}

\section{The Effect of Different Placement Zones on Closed Housed on Microclimatic Ammonia, Relative Weight of Lymphoid Organs, Thyroid Gland, and Small Intestine in Chicken Broiler's}

\author{
Wahyu Fajar Arfianta, Teysar Adi Sarjana*, Endang Widiastuti \\ Program Studi S1 Peternakan, Fakultas Peternakan dan Pertanian, Universitas Diponegoro \\ Kampus Jl. drh. Koesoemowardojo, Tembalang Semarang 50275 \\ *Penulis Korespondensi : teysaradisarjana@lecturer.undip.ac.id
}

\begin{abstract}
ABSTRAK
Tujuan dari penelitian ini adalah untuk mengetahui pengaruh zona penempatan yang berbeda pada closed housed terhadap mikroklimatik amonia, bobot relatif organ limfoid, kelenjar tiroid, dan usus halus pada ayam broiler. Materi yang digunakan dalam penelitian yaitu ayam broiler sebanyak 360 ekor yang diambil dari populasi 11.000 ekor dengan bobot badan awal 44,8 $\pm 1,66$ g. Rancangan yang digunakan adalah Rancangan Acak Kelompok dengan 4 perlakuan dan 6 kelompok sehingga terdapat 24 unit percobaan dan masing-masing unit berisi 15 ekor. Perlakuan yang diberikan adalah $\mathrm{T} 1=$ zona $1 ; 0 \mathrm{~m}$ dari inlet, $\mathrm{T} 2=$ zona $2 ; 15 \mathrm{~m}$ dari inlet, $\mathrm{T} 3=$ zona $3 ; 30 \mathrm{~m}$ inlet, $\mathrm{T} 4=$ zona $4 ; 45 \mathrm{~m}$ dari inlet. Parameter yang diukur meliputi mikroklimatik amonia pada zona berbeda, bobot organ limfoid, kelenjar tiroid, panjang dan bobot usus halus. Hasil analisis ragam yang telah dilakukan dapat diketahui bahwa perubahan mikroklimatik amonia pada zona penempatan berbeda tidak berpengaruh nyata $(\mathrm{P}>0,05)$ terhadap bobot relatif organ limfoid, panjang dan bobot usus halus pada ayam broiler. Simpulan dari penelitian ini adalah zona penempatan berbeda dalam kandang closed house yang diikuti dengan perubahan mikroklimatik amonia tidak mempengaruhi bobot relatif organ limfoid, kelenjar tiroid, dan usus halus pada ayam broiler.
\end{abstract}

Kata kunci : amonia, ayam broiler, closed housed, organ limfoid, zona. 


\begin{abstract}
The purpose of this study is to determine the effect of different placement zones on closed housed on microclimatic ammonia, relative weight of lymphoid organs, thyroid gland, and small intestine in broiler chickens. The material used in the study was 360 broiler chickens taken from a population of 11000 with an initial body weight of $44.8 \pm 1.66 \mathrm{~g}$. The design used was a randomized block design with 4 treatments and 6 groups so that there were 24 experimental units and each unit contained 15 heads. The treatment given is $\mathrm{T} 1=0 \mathrm{~m}$ from the inlet, $\mathrm{T} 2=15 \mathrm{~m}$ from the inlet, $\mathrm{T} 3=30 \mathrm{~m}$ inlet, $\mathrm{T} 4=$ $45 \mathrm{~m}$ from the inlet. The parameters measured include ammonia microclimatics in different zones, the weight of lymphoid organs, thyroid gland the length and weight of broiler small intestine. The results of the analysis of variance that has been done can be seen that changes in ammonia microclimatics in different placement zones had no significant effect $(P>0.05)$ on the relative weight of lymphoid organs, thyroid gland the length and weight of broiler small intestine in broiler chickens.. The conclusion of this study is that the different placement zones in the closed house enclosure followed by ammonia microclimatic changes have not been able to influence the relative size of , the weight of lymphoid organs, thyroid gland the length and weight of broiler small intestine in broiler chickens.
\end{abstract}

Keywords: ammonia, broiler, closed house, lymphoid organs, zone.

\section{PENDAHULUAN}

Kandang closed housed merupakan kandang tertutup dengan tujuan untuk mengurangi pengaruh mikroklimat dan membatasi kontak langsung dengan organisme lain. Kelebihan kandang closed housed yaitu memudahkan pengawasan, memudahkan pengaturan suhu, kelembaban, cahaya, dan ventilasi sehingga penyebaran penyakit mudah diatasi (Susanti et al., 2017). Kandang closed housed dengan sistem ventilasi yang baik mampu mengurangi tingkat stress yang diterima oleh ternak, namun apabila manajemen kandang buruk maka akan berpengaruh buruk pula terhadap ternak, salah satunya adalah meningkatnya kadar amonia sehingga dapat mempengaruhi produktivitas ayam broiler.

Amonia adalah gas alkalin yang tidak berwarna dan mempunyai daya iritasi tinggi yang merupakan produk dekomposisi dari senyawa organik dalam ekskreta yang tidak teroksidasi dengan sempurna. Proses pembentukan amonia meningkat pada suhu yang tinggi dengan meningkatkan $\mathrm{pH}$ litter dan dipengaruhi oleh tinggi atau rendahnya kelembaban dalam kandang. Kadar amonia yang tinggi dalam kandang akan mengganggu kesehatan ayam yang mengarah ke masalah pernapasan dan lainnya (Ritz, 2002). Gas amonia akan menyebabkan gangguan kesehatan seperti iritasi kulit, mata, dan gangguan pernapasan sehingga mengganggu 
produktivitas ayam. Pada musim penghujan, suhu yang rendah dengan kelembaban yang tinggi dapat mempengaruhi produksi amonia menjadi lebih tinggi dibandingkan dengan musim kemarau karena alas kandang menjadi lebih mudah basah.

Panjang kandang closed house dapat mengakibatkan perbedaan produksi amonia sehingga diperkirakan dapat mengganggu sistem kekebalan tubuh dan menurunkan produktivitas ayam broiler. Semakin jauh jarak dari inlet memiliki kadar amonia yang lebih tinggi, hal ini dikarenakan aliran udara dari lokasi yang dekat dengan inlet menuju ke arah outlet. Kadar amonia $\left(\mathrm{NH}_{3}\right)$ yang mencapai 20 ppm dapat mempengaruhi sistem imun, sehingga ayam mudah terkena penyakit yang berakibat pada penurunan bobot badan dan feed convertion ratio (FCR) (Maliselo dan Nkonde, 2015).

Organ limfoid merupakan organ yang berperan dalam sistem kekebalan tubuh unggas yang terdiri dari organ limfoid primer yaitu bursa fabrisius dan timus serta organ limfoid sekunder yaitu limpa (Jamilah et al., 2013). Organ limfoid ayam berperan dalam menjaga sistem kekebalan tubuh dengan menghasilkan sel antibodi atau yang sering disebut dengan sel limfosit yang berinteraksi dengan antigen yang masuk dalam tubuh

\section{MATERI DAN METODE}

Penelitian dilaksanakan di Kandang Closed House, Laboratorium Produksi Ternak Unggas, Fakultas Peternakan dan Pertanian, Universitas Diponegoro, Semarang. Materi yang digunakan ayam broiler sebanyak 360 ekor yang diambil dari populasi 11.000
(Masum et al., 2014). Limpa merupakan organ limfoid sekunder yang membantu pematangan dan seleksi sel-sel limfoid (Herwajuli dan Dharmayanti, 2015).

Usus halus terdiri dari duodenum, jejenum, dan ileum yang di dalamnya terdapat jaringan villi yang berfungsi untuk menyerap nutrisi dalam pakan. Semakin tinggi villi usus halus maka dapat menciptakan kondisi yang ideal bagi bakteri dan menguntungkan saluran pencernaan, sehingga menekan pertumbuhan bakteri patogen. Kondisi tersebut berakibat pada kekebalan mukosa (gut-associated lymphoid tissue/GALT). Organ kekebalan tubuh unggas yaitu organ limfoid yang terdiri dari organ limfoid primer dan organ limfoid sekunder yaitu bursa fabrisius, timus dan limpa (Toghyani et al., 2010).

Tujuan dari penelitian ini adalah untuk mengetahui pengaruh zona penempatan yang berbeda pada closed housed terhadap mikroklimatik amonia, bobot relatif organ limfoid, kelenjar tiroid, dan usus halus pada ayam broiler. Manfaat dari penelitian ini yaitu untuk memberikan informasi hasil penelitian mengenai pengaruh zona penempatan terhadap mikroklimatik amonia, bobot relatif organ limfoid, kelenjar tiroid, dan usus halus pada ayam broiler.

ekor dalam kandang closed housed dengan berat badan awal 44,8 $\pm 1,66$ g. Ukuran kandang closed housed yang digunakan dengan lebar $12 \mathrm{~m}$ dan panjang $60 \mathrm{~m}$, pakan yang digunakan berupa complete feed dengan kode S-10 dan S-12 produksi PT. Charoen Pokphand Indonesia. Peralatan yang digunakan meliputi ammonia detector, timbangan gantung 
kapasitas $50 \mathrm{~kg}$, jaring, $\mathrm{pH}$ meter dan thermohygrometer, termometer digital, pita ukur dan timbangan analitik dengan ketelitian $0,001 \mathrm{~g}$.

Rancangan yang digunakan adalah Rancangan Acak Kelompok (RAK) dengan 4 perlakuan dan 6 kelompok penempatan broiler sehingga terdapat 24 unit percobaan dan tiap kelompok terdiri dari 15 ekor ayam broiler. Perlakuan yang digunakan adalah $\mathrm{T} 1=0 \mathrm{~m}$ dari inlet, $\mathrm{T} 2=15 \mathrm{~m}$ dari inlet, $\mathrm{T} 3=30 \mathrm{~m}$ inlet, $\mathrm{T} 4=45 \mathrm{~m}$ dari inlet. Parameter yang diukur meliputi mikroklimat kandang dimulai dari hari ke 0-28, bobot organ limfoid, kelenjar tiroid, dan panjang serta bobot usus halus ayam broiler dilakukan setelah ayam dipanen kemudian ditimbang menggunakan timbangan analitik dengan ketelitian 0,001 g. Data dianalisis dengan analisis ragam pada taraf 5\% apabila berpengaruh nyata maka dilanjutkan dengan uji Duncan pada taraf $5 \%$.

\section{HASIL DAN PEMBAHASAN}

Bobot relatif organ limfoid ayam broiler dalam penelitian ini meliputi bursa fabrisius, limpa dan timus, serta kelenjar tiroid. Berdasarkan hasil penelitian diperoleh rata-rata bobot relatif organ limfoid yang disajikan pada Tabel 1.

Tabel 1. Rata-rata Bobot Relatif Organ Limfoid dan Kelenjar Tiroid

\begin{tabular}{lcccc}
\hline \hline \multirow{2}{*}{ Parameter } & \multicolumn{4}{c}{ Perlakuan } \\
\cline { 2 - 5 } & $\mathrm{T} 1$ & $\mathrm{~T} 2$ & $\mathrm{~T} 3$ & $\mathrm{~T} 4$ \\
\hline Bursa Fabrisius (\%) & 0,07 & 0,05 & 0,06 & 0,08 \\
Limpa (\%) & 0,09 & 0,10 & 0,10 & 0,11 \\
Timus (\%) & 0,33 & 0,35 & 0,32 & 0,30 \\
Kelenjar Tiroid (mg/100g bobot hidup) & 3,00 & 4,00 & 4,00 & 3,40 \\
\hline
\end{tabular}

Keterangan: T1 = $0 \mathrm{~m}$ dari inlet, T2 = $15 \mathrm{~m}$ dari inlet, T3 = $30 \mathrm{~m}$ inlet, T4=45 $\mathrm{m}$ dari inlet.

Berdasarkan Tabel 1 dapat diketahui bahwa bobot bursa fabrisius pada T1 sampai T4 berkisar antara 0,05 0,08\% tertinggi pada $\mathrm{T} 4$ dan terendah pada T2 yang berarti berada di bawah rata-rata bobot bursa fabrisius. Menurut Toghyani et al. (2010) bahwa bobot relatif bursa fabrisius pada ayam sebesar 0,09\% dari bobot hidup. Uji statistik menunjukkan bahwa perubahan mikroklimatik amonia pada zona penempatan berbeda tidak berpengaruh nyata $(\mathrm{P}>0,05)$ terhadap bobot relatif bursa fabrisius. Hal ini diduga disebabkan karena kadar amonia tertinggi sebesar 6,23 ppm yang artinya masih di bawah ambang batas aman untuk ayam broiler. Ritz et al. (2004) melaporkan bahwa kandungan amonia yang aman dan belum menimbulkan gangguan pada ayam ialah di bawah 20 ppm.

Selain kadar amonia, kondisi kandang masih dalam kondisi nyaman berdasarkan besarnya discomfort index. Menurut Kusnadi (2009) bahwa faktor yang mempengaruhi ukuran bursa fabrisius adalah tingginya hormon kostikosteron, dimana meningkatnya hormon kortikosteron pada ternak salah satunya dapat disebabkan karena ternak mengalami cekaman panas (Yunianto, 1999).

Bobot relatif limpa pada T1 sampai T4 bekisar antara 0,09-0,11\% yang berarti masih dalam batas normal. Wijaya (2010) 
menyatakan bahwa bobot limpa berkisar antara 0,09-0,12\% dari bobot hidup ayam. Uji statistik menunjukkan bahwa perubahan mikroklimatik amonia pada zona penempatan berbeda tidak berpengaruh nyata $(\mathrm{P}>0,05)$ terhadap bobot limpa. Hal ini disebabkan karena kondisi kandang yang masih nyaman berdasarkan besarnya Discomfort Index dalam kandang termasuk dalam kategori nyaman. Menurut Sturkie (2000) ukuran limpa mengecil akibat terjadinya imunosupresi atau cekaman panas dalam waktu lama.

Bobot relatif timus pada T1-T4 masih berada pada kisaran normal antara 0,30-0,35\%. Zhang et al. (2013) melaporkan bahwa bobot relatif timus rata-rata antara $0,26-0,38 \%$. Uji statistik menunjukkan bahwa perubahan mikroklimatik amonia pada zona penempatan berbeda tidak berpengaruh nyata $(\mathrm{P}>0,05)$ terhadap bobot relatif timus. Hal ini disebabkan karena kondisi kandang yang termasuk kategori nyaman, ternak tidak dalam kondisi stres sehingga tidak memicu kerja timus yang menyebabkan bobot relatif tetap normal. Tizzard (1987) menyatakan bahwa timus mengalami atrofi cepat jika ayam broiler mengalami stres sehingga ukurannya semakin mengecil.

Bobot relatif kelenjar tiroid berdasarkan Tabel 1 pada T1 - T4 berada di bawah kisaran normal antara 3,00-4,00 $\mathrm{mg} / 100 \mathrm{~g}$ bobot hidup atau setara dengan 0,0030 - 0,0040\%. Subekti (2009) melaporkan bahwa rata-rata bobot tiroid ayam broiler berkisar 6,323 - 6,529 $\mathrm{mg} / 100 \mathrm{~g}$ bobot hidup. Hasil penelitian Sturkie (2000) menunjukkan bahwa bobot kelenjar tiroid unggas berkisar antara 0,004 - 0,007\% dari bobot hidup. Uji statistik pada penelitian ini tidak berpengaruh nyata $(\mathrm{P}>0,05)$ terhadap bobot kelenjar tiroid, yang disebabkan besarnya mikroklimatik ammonia di zona penempatan terjauh dari inlet sebesar 6,24 ppm yang artinya masih berada di bawah standar.

Faktor yang mempengaruhi bobot kelenjar tiroid salah satunya yaitu suhu lingkungan. Syahrudin et al. (2012) menyatakan bahwa suhu lingkungan yang tinggi (panas) akan menyebabkan hypothalamus mengurangi/menekan produksi thyroid realizing factor (TRF) sehingga rangsangan ke hypofisa anterior untuk mensekresikan thyroid stimulating hormone (TSH) jadi berkurang dan menyebabkan produksi tiroksin jadi berkurang sehingga kadar tiroksin dalam darah menjadi rendah.

Bobot relatif usus halus ayam broiler yang diamati dalam penelitian ini meliputi duodenum, jejenum dan ileum. Berdasarkan hasil penelitian diperoleh rata - rata bobot relatif usus halus yang disajikan pada Tabel 2.

Tabel 2. Rata-rata Bobot Relatif Usus Halus

\begin{tabular}{lrrrr}
\hline \multirow{2}{*}{ Parameter } & \multicolumn{4}{c}{ Perlakuan } \\
\cline { 2 - 4 } & T1 & T2 & T3 & T4 \\
\hline \hline & & --1 & & \\
Duodenum & 0,72 & 0,71 & 0,65 & 0,88 \\
Jejenum & 1,12 & 0,98 & 1,09 & 1,08 \\
Ileum & 0,92 & 0,81 & 0,85 & 1,02 \\
\hline
\end{tabular}

Keterangan: T1 = $0 \mathrm{~m}$ dari inlet, T2 = $15 \mathrm{~m}$ dari inlet, T3 = $30 \mathrm{~m}$ inlet, T4=45 $\mathrm{m}$ dari inlet. 
Bobot usus yang normal dapat menunjukkan bahwa ayam broiler dalam kondisi sehat. Usus halus merupakan organ pencernaan yang berfungsi untuk mengabsorbsi pakan. Nutrisi pakan yang tidak tercerna sempurna dapat menyebabkan produksi amonia meningkat sehingga mempengaruhi lingkungan ternak. Kadar amonia pada penelitian ini menunjukkan angka 6,23 ppm tidak mampu mempengaruhi rataan bobot relatif usus halus. Saputra et al. (2015) menyatakan bahwa amonia akan mempengaruhi fisiologis ayam broiler di atas $25 \mathrm{ppm}$.

Bobot relatif duodenum (Tabel 2) pada T1 - T4 menunjukkan angka 0,65 $0,88 \%$ yang berarti masih dalam taraf normal pada T4 sedangkan T1 - T3 berada di bawah taraf normal. Djunaidi et al. (2009) menyatakan bahwa bobot relatif duodenum sebesar 0,81 - 0,96\% dari bobot hidup ayam. Uji statistik menunjukkan bahwa zona penempatan yang berbeda tidak berpengaruh nyata $(\mathrm{P}>0,05)$ terhadap bobot relatif duodenum. Hal ini disebabkan karena perubahan mikroklimatik amonia masih dalam batas ambang yang diijinkan sehingga kondisi kandang masih nyaman. Kusnadi (2007) menyatakan bahwa suhu udara yang tinggi dapat mempengaruhi bobot usus halus ayam broiler karena kinerja usus halus berkurang akibat konsumsi minum lebih tinggi dibandingkan konsumsi pakan.

Bobot relatif jejenum (Tabel 2) berkisar antara 0,98-1,12\% yang berarti berada pada kisaran normal bobot relatif jejenum, hasil penelitian Elisa et al. (2017) berkisar antara 1,00-1,05\%. Uji statistik menunjukkan perubahan mikroklimatik amonia pada zona penempatan berbeda tidak berpengaruh nyata $(P>0,05)$ terhadap bobot relatif jejenum. Yunianto (1998) menyatakan bahwa ayam yang terkena cekaman panas memiliki bobot badan yang lebih rendah dibandingkan terkena cekaman dingin. Hal ini dikarenakan ayam lebih banyak mengkonsumsi air daripada pakan sehingga menurunkan kinerja usus.

Bobot relatif ileum berkisar antara $0,81-0,92 \%$ dan berada di atas normal pada T1 dan T4 sedangkan T2 dan T3 masih berasa pada kisaran normal. Pertiwi et al. (2017) bahwa bobot relatif ileum bekisar antara 0,63 - 0,89\%. Uji statistik menunjukkan bahwa perlakuan tidak berpengaruh nyata $(\mathrm{P}>0,05)$ terhadap bobot relatif ileum. Lutfiana et al. (2015) menyatakan bahwa suhu yang tinggi dapat menghambat penyerapan nutrisi pakan sehingga kinerja usus tidak maksimal dan mempengaruhi bobot usus halus. Kesehatan ayam broiler juga mempengaruhi kinerja usus halus dalam mengabsorbsi pakan, sehingga saluran pencernaan dapat berkembang dengan baik dan produktivitas ayam meningkat.

Panjang relatif usus halus ayam broiler yang diamati dalam penelitian ini meliputi duodenum, jejenum dan ileum. Berdasarkan hasil penelitian diperoleh rata-rata panjang relatif usus halus yang disajikan pada Tabel 3.

Panjang relatif duodenum (Tabel 3) dari T1 sampai T4 pada kisaran angka $1,97-2,74 \%$ yang berarti berada di atas kisaran normal panjang relatif duodenum hasil penelitian Pertiwi et al. (2017) kisaran 1,61-2,01\%. Uji statistik menunjukkan bahwa perubahan mikroklimatik amonia pada zona penempatan berbeda tidak berpengaruh nyata $(P>0,05)$ terhadap panjang relatif duodenum. Faktor yang mempengaruhi panjang relatif duodenum yaitu 


\section{DAFTAR PUSTAKA}

Djunaidi, I. H., T. Yuwanta, Supadmo, dan M. Nurcahyanto. 2009. Performa dan bobot organ pencernaan ayam broiler yang diberi pakan limbah udang hasil fermentasi Bacillus sp. Jurnal Media Peternakan 32(2):212-219.

Elisa W., E. Widhiastuti, dan T. A. Sarjana. Bobot relatif organ limfoid dan usus halus ayam broiler yang disuplementasi probiotik Bacillus plus. Prosiding Seminar Teknologi dan Agribisnis Peternakan. 297301.

Ibrahim, S. 2008. Hubungan ukuranukuran usus halus dengan berat badan broiler. Jurnal Agripet 8(2):42-46.

Jamilah, N. Suthama, dan L. D. Mahfudz. 2013. Performa produksi dan ketahanan tubuh broiler yang diberi pakan step down dengan penambahan asam sitrat sebagai acidifier. JITV 18 (4): 251-257.

Jamilah, N. Suthama, dan L. D. Mahfudz. 2014. Pengaruh penambahan jeruk nipis sebagai acidifier pada pakan step down terhadap kondisi usus halus ayam pedaging. JITP 3(2):9095.

Herwajuli, D. A dan N. L. P. I. Dharmayanti. 2015. Peran sistem kekebalan non-spesifik dan spesifik pada unggas terhadap Newcastle Disease. Wartazoa. 25(3):135-146.

Kusnadi, E. 2007. Pengaruh penambahan Pegagan (Centella asiatica) dan vitamin $C$ terhadap kandungan hemoglobin dan hematokrit darah ayam broiler yang mengalami cekaman panas. Jurnal Ilmu Ternak. 7(2):10-14.
Kusnadi, E. 2009. Perubahan malonaldehida hati, bobot relatif bursa fabrisius dan rasio heterofil/limfosit ayam broiler yang diberi cekaman panas. Media Peternakan. 32(2):81-87.

Lutfiana, K., T. Kurtini, dan M. Hartono. 2015. Pengaruh pemberian probiotik dari mikroba lokal terhadap gambaran darah ayam petelur. JIPT. 3(3):151-156.

Maliselo, P. S and G. K. Nkonde. 2015. Ammonia production in poultry houses and its effect on the growth of Gallus gallus domestica. Int. Jour. Of Sci. And Tech. Res. 4:141-145.

Masum, M. D. A., M. Z. I. Khan., M. Nasrin., M. N. H. Siddiq, and M. D. N. Islam. 2014. Detection of immunoglobulins containing plasmacells in the tymus, bursa of fabricius and spleen of vaccinated broiler chickens with Newcastle disease virus vaccine. Int. J. Vet. Sci. And Med. 2:103-108.

Pertiwi, D. D. R., R. Murwani, dan T, Yudiarti. 2017. Bobot relatif saluran pencernaan ayam broiler yang diberi tambahan air rebusan kunyit dalam air minum. Jurnal Peternakan. 19(2):60 - 64 .

Ritz, C. W, B. D. Fairchild, and M. P. Lacy. 2004. Implications of ammonias production and emissions from commercial poultry facilities: A Review. J. Appl. Poult. Res. 13:684-692.

Ritz, C. W. 2002. Litter Quality And Broiler Performance. The University of Georgia College of Agriculture and Environment Sciences. United State of America.

Saputra T. H., K. Nova, dan D. Septinova. 2015. Pengaruh penggunaan 
berbagai jenis litter terhadap bobot hidup, karkas, giblet dan lemak abdominal broiler fase finisher di close house. JIPT. 3(1):38-44.

Sturkie, P.D. 2000. Avian Physiology. $4^{\text {th }}$ Edition. Springer-Verlag, New York.

Subekti, K. 2009. Pengaruh pola waktu pemberian pakan dengan suplementasi beberapa level Vitamin C terhadap performans produksi dan organ fisiologis ayam broiler. Jurnal Ilmu-Ilmu Peternakan. 12(4):203-213.

Suprijatna, E., U. Atmomarsono, dan R. Kartasudjana. 2005. Ilmu Dasar Ternak Unggas. Penebar Swadaya, Jakarta.

Susanti, E. D., M. Dahlan, dan D. Wahyuning. 2017. Perbandingan produktivitas ayam broiler terhadap sistem kandang terbuka (open house) dan kandang tertutup (closed house) di UD. Sumber Makmur Kecamatan Sumberrejo Kabupaten Bojonegoro. Jurnal Ilmu-Ilmu Peternakan 25:16-23.

Syahruddin, E., H. Abbas, E. Purbowati, dan Y. Heryandi. 2012. Aplikasi mengkudu sebagai sumber antioksidan untuk mengatasi stress ayam broiler di daerah tropis. Jurnal Ilmu Peternakan. 14 (3): 411 424.

Tamalludin, F. 2014. Ayam Broiler 22 Hari Panen Lebih Menguntungkan. Penebar Swadaya, Jakarta.

Tizzard, I. 1987. Veterinary Immunology an Introduction. W.B. Saunder Company. Philadelphia, USA. 1387.

Toghyani, M., Tohidi, M., Gheisari, A.A and Tabeidian, S.A. 2010. Performance, immunity, serum biochemical and hematological parameters in broiler chicks fed dietary thyme as alternative for an antibiotic growth promoter. Afr J Biotechnol. 9:6819-6825.

Wijaya, G. H. 2010. Persentase karkas, lemak abdominal dan organ dalam ayam broiler yang diberi ransum penambahan dedak padi. Jurnal Fishtech, 1 (1): 78-90.

Yunianto, V. D. 1998. Performans ayam broiler pada berbagai kondisi temperatur lingkungan. Jurnal Pengembangan Peternakan Tropis. 24 (4):149-156.

Yunianto, V. D. 1999. Pengaruh cekaman dingin dan panas terhadap percepatan pembongkaran protein pada ayam broiler. Jurnal Pengembangan Peternakan tropis. 24(2):90-96.

Zhang, Z.F., J.H. Cho, and I.H. Kim. 2013. Effects of Bacillussubtilis UBT-MO2 on growth performance, relative immune organ weight, gas concentration in excreta, and intestinal microbials hedding in broiler chickens. J. Livestock Sci. 155:343-347. 